\title{
The effects of air pollutants on the mortality rate of lung cancer and leukemia
}

\author{
MANSOOREH DEHGHANI ${ }^{1}$, LAILA KESHTGAR ${ }^{1}$, MOHAMMAD REZA JAVAHERI $^{1}$, ZAHRA DERAKHSHAN $^{2}$ \\ GEA OLIVERI CONTI ${ }^{3}$, PIETRO ZUCCARELLO ${ }^{3,4}$ and MARGHERITA FERRANTE ${ }^{3}$ \\ ${ }^{1}$ Research Center for Health Sciences, Department of Environmental Health, School of Health, Shiraz University \\ of Medical Sciences, Shiraz; ${ }^{2}$ Environmental Science and Technology Research Center, Department of Environmental \\ Health Engineering, School of Public Health, Shahid Sadoughi University of Medical Sciences, Yazd, Iran; \\ ${ }^{3}$ Environmental and Food Hygiene Laboratories (LIAA), Department of Medical Sciences, Surgical and \\ Advanced Technologies 'G.F. Ingrassia', Hygiene and Public Health, University of Catania; ${ }^{4}$ Department \\ of Biological, Geological and Environmental Science of University of Catania, Catania, Italy
}

Received December 20, 2016; Accepted February 7, 2017

DOI: $10.3892 / \mathrm{mmr} .2017 .6387$

\begin{abstract}
World Health Organization classifies air pollution as the first cause of human cancer. The present study investigated impact of air pollutants on the mortality rates of lung cancer and leukemia in Shiraz, one of the largests cities of Iran. This cross-sectional (longitudinal) study was carried out in Shiraz. Data on six main pollutants, $\mathrm{CO}, \mathrm{SO}_{2}, \mathrm{O}_{3}, \mathrm{NO}_{2}, \mathrm{PM}_{10}$ and $\mathrm{PM}_{2.5}$, were collected from Fars Environmental Protection Agency for 3,001 days starting from 1 January, 2005. Also, measures of climatic factors (temperature, humidity, and air pressure) were obtained from Shiraz Meteorological Organization. Finally, data related to number of deaths due to lung and blood cancers (leukemia) were gathered from Shiraz University Hospital. Relationship between variations of pollutant concentrations and cancers in lung and blood was investigated using statistical software $\mathrm{R}$ and MiniTab to perform time series analysis. Results of the present study revealed that the mortality rate of leukemia had a direct significant correlation with concentrations of nitrogen dioxide and carbon monoxide in the air $(\mathrm{P}<0.05)$. Therefore, special attention should be paid to sources of these pollutants and we need better management to decrease air pollutant concentrations through, e.g., using clean energy respect to fossil fuels, better management of urban traffic planning, and the improvement of public transport service and car sharing.
\end{abstract}

Correspondence to: Dr Gea Oliveri Conti, Environmental and Food Hygiene Laboratories (LIAA), Department of Medical Sciences, Surgical and Advanced Technologies 'G.F. Ingrassia', Hygiene and Public Health, University of Catania, via Santa Sofia 87, I-95123 Catania, Italy

E-mail: olivericonti@unict.it

Key words: blood cancer (leukemia), lung cancer, air pollution, time series analysis, cross-sectional study

\section{Introduction}

Unplanned expansions of cities, along with economic development and to rising energy demand, have caused numerous environmental problems and serious risks for human health. Indeed, air pollution has always been a serious threat for society health and for environment on the global scale (1-3).

Industries, urban traffic and combustion of fossil fuels for energy production are main sources of most of the organic and mineral compounds, oxidants and acids, and fine particles. They play a significant role in air pollution of most of the urban areas (4).

Impact of air pollution on human health has been investigated for many years. Mechanisms through which air pollution affects human health are very complex and not yet fully understood (5).

Since nasal cavity is the most common route of entrance of pollutants into the body, the combinations of gases, fine particles and chemical compounds in the indoor and outside environments can have adverse effects on health. Moreover, respiratory mucosa is very vulnerable to degeneration. It is the first organ damaged in its functionality due to air pollution (6-10). However, the consequences of long-term exposure to air pollution have not been clarified.

Epidemiological researches confirmed there is a direct relationship among air pollution and respiratory disease symptoms, lung failure, chronic bronchitis and number of deaths due to respiratory problems (11).

Various epidemiological studies, carried out in the USA and Europe, showed that air pollution might increase risk of lung cancer (12) and the mortality rate due to cardiovascular strokes (13). Other studies, also conducted in USA, showed there is a direct relationship between rate of mortality and the amount of sulphate and other pollutants in the air (14).

Thus, air pollution has been declared by the World Health Organization (WHO) as one of main causes of human cancer (5).

$\mathrm{PM}_{10}$ plays a leading role in different respiratory symptoms. Indeed, they cause temporal alteration of lung function 
and, so, they cause increase of respiratory disease rate and hospital admissions and the morbidity rate of cardiovascular diseases (15-19).

In 2005 edition of Air Quality Guideline, WHO established that nitrogen dioxide $\left(\mathrm{NO}_{2}\right)$, ozone $\left(\mathrm{O}_{3}\right)$, sulfur trioxide $\left(\mathrm{SO}_{3}\right)$, and particulate matter (PM) are air pollutants that affect human health significantly (1). The Environmental Protection Agency (EPA) fixed National Ambient Air Quality Standards for six principal pollutants, which are called 'criteria' air pollutants (2).

Although, since the first decade of the 20th century, some air pollution control programs have been conducted in many industrially developed countries to preserve human health and prevent environmental pollution, actually air quality is daily getting worse in most developing countries (1). Due to growth of air pollution, the residents have an increased risk perception of respiratory diseases (20).

Shiraz is the third largest city of Iran in terms of extension also it is in a special geographical location (being enclosed by mountains). Shiraz has both a high density of industries near urban area and a major urban traffic. All these factors lead to air pollution increase in the city.

Therefore, the main aim of the present study was to investigate the relationship between air pollutants and mortality rate related to leukemia and lung cancer.

\section{Materials and methods}

Pollutant data. This longitudinal study was carried out in Shiraz. Data on six main air pollutants, $\mathrm{CO}, \mathrm{SO}_{2}, \mathrm{O}_{3}, \mathrm{NO}_{2}, \mathrm{PM}_{10}$ and $\mathrm{PM}_{2.5}$ were obtained from Fars Environmental Protection Agency and these data are related to 3,001 measurement days starting from, 1 January, 2005. These data were collected from two fixed monitoring stations located at opposite points of the city (Kazeroon gate and Imam Hussein square). Moreover, the daily minimum, maximum and average measurements of climatic factors such as temperature, humidity, wind speed and air pressure were obtained from Shiraz Meteorological Organization. Additionally, we considered rainfall, sunshine hours and daily evaporation rate.

Although meteorological data were complete, data related to air pollutants had some missing days. Lack of measurements of some pollutants in different times may have different reasons including obstruction of the filter that measure specific pollutants, blackout of electricity due to technical reasons. Thus, when data were accessible from both stations, we used mean concentration of pollutants to be more accurate.

However, some days, no information was available from any station. We used statistical methods to forecast pollutant concentrations in these cases: i) time series method was used for prediction in case that missing data were $<5 \%$ of the earlier period, e.g., data related to $\mathrm{CO}$ concentration were completed using this method. ii) Missing items, which were $>5 \%$ of the earlier period, were predicted by these data and by nonlinear regression method.

In total, more than 2,000 different models were used for all variables in this study to complete data properly.

Finally, data related to number of deaths due to both lung cancer and leukemia, in the investigated period, were obtained from Shiraz University Hospital.
Table I. Fitting models for cancer data.

Sites of cancer

Models (p, d, q)

Lung cancer in male

$\mathrm{NA}^{\mathrm{a}}$

Lung cancer in female

$\mathrm{NA}^{\mathrm{a}}$

Lymphoid cancer in male

ARIMA $(0,0,0)$

Lymphoid cancer in female

ARIMA $(0,0,0)$

Myeloid cancer in male

$\mathrm{NA}^{\mathrm{a}}$

Myeloid cancer in female

ARIMA $(0,0,0)$

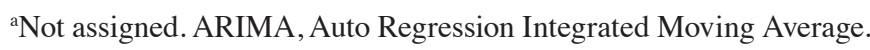

Table II. Fitting models for air pollution data.

\begin{tabular}{ll}
\hline Air pollutant parameters & Models $(\mathrm{p}, \mathrm{d}, \mathrm{q})$ \\
\hline $\mathrm{CO}$ & $\operatorname{IMA}(0,1,8)$ \\
$\mathrm{PM}$ & ARMA $(2,0,2)$ \\
$\mathrm{NO}$ & $\operatorname{IMA}(0,1,15)$ \\
$\mathrm{NO}_{2}$ & ARIMA $(1,1,14)$ \\
$\mathrm{NO}_{\mathrm{X}}$ & IMA $(0,1,14)$ \\
$\mathrm{O}_{3}$ & IMA $(0,1,11)$ \\
\hline
\end{tabular}

$\mathrm{PM}$, particulate matter; $\mathrm{NO}_{2}$, nitrogen dioxide; $\mathrm{O}_{3}$, ozone; IMA, Integrated Moving Average; ARMA, Autoregressive Moving Average; ARIMA, Auto Regression Integrated Moving Average.

Table III. Fitting models for meteorological data.

\begin{tabular}{ll}
\hline Meteorological parameters & Models $(\mathrm{p}, \mathrm{d}, \mathrm{q})$ \\
\hline Minimum temperature & $\operatorname{IMA}(0,1,16)$ \\
Maximum temperature & $\operatorname{ARIMA~}(2,1,14)$ \\
Mean temperature & $\operatorname{ARIMA}(1,1,12)$ \\
Minimum humidity & $\operatorname{IMA}(0,1,7)$ \\
Maximum humidity & $\operatorname{ARIMA~}(1,1,2)$ \\
Precipitation & $\operatorname{ARMA}(1,0,7)$ \\
Sunshine & $\operatorname{ARMA}(1,0,3)$ \\
Evaporation & $\operatorname{ARIMA~}(2,1,2)$ \\
Maximum wind velocity & $\operatorname{IMA}(0,1,2)$
\end{tabular}

IMA, Integrated Moving Average; ARIMA, Auto Regression Integrated Moving Average; ARMA, Autoregressive Moving Average.

Statistical analysis. Principal component analysis was performed on the meteorological variables and three major factors, were selected. Based on this statistical model, maximum and minimum temperature, maximum humidity and evaporation were replaced only by mean temperature variable. The variables known as sunshine magnitude and rainfall level were replaced only by rainfall level. Additionally, the maximum wind speed was considered as a separate factor. Then, correlation of the above factors with pollutants and cancers was analyzed and the correlation coefficient was determined. 


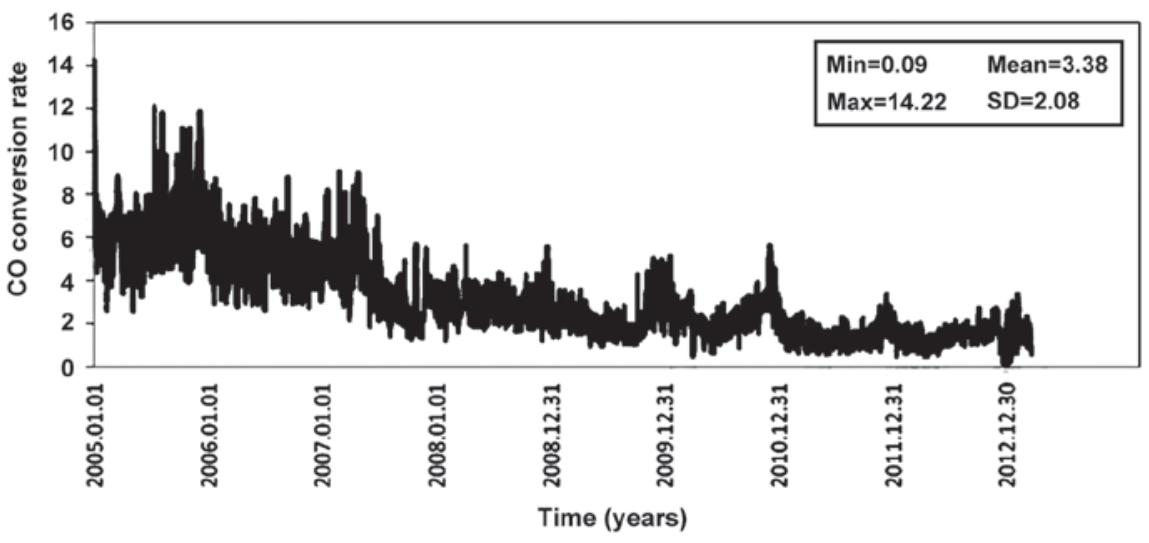

Figure 1. The variation of CO conversion rate during 2004-2012.

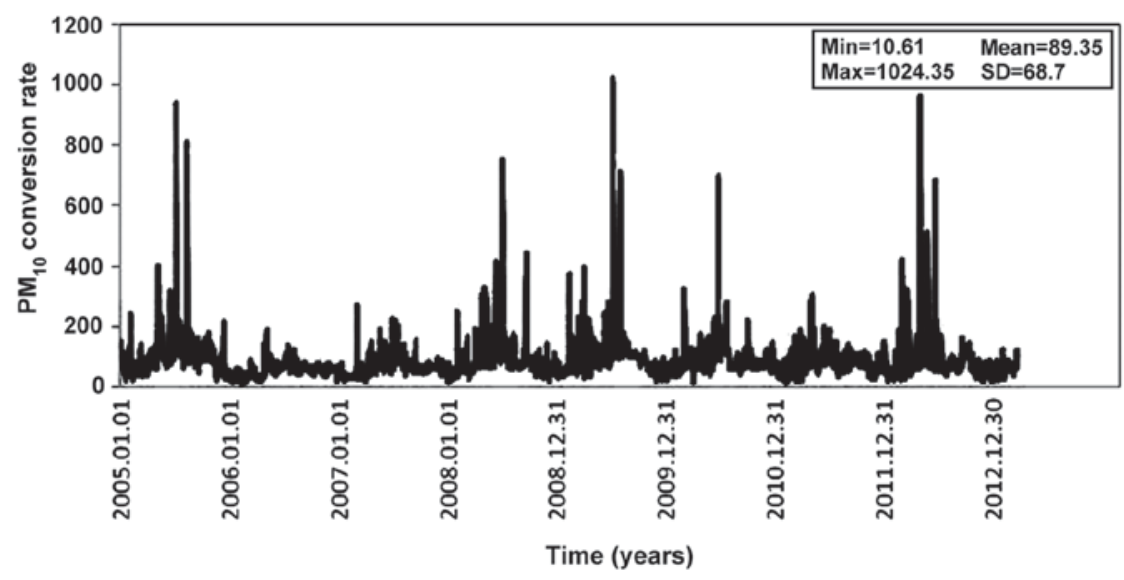

Figure 2. The variation of $\mathrm{PM}_{10}$ conversion rate during 2004-2012.

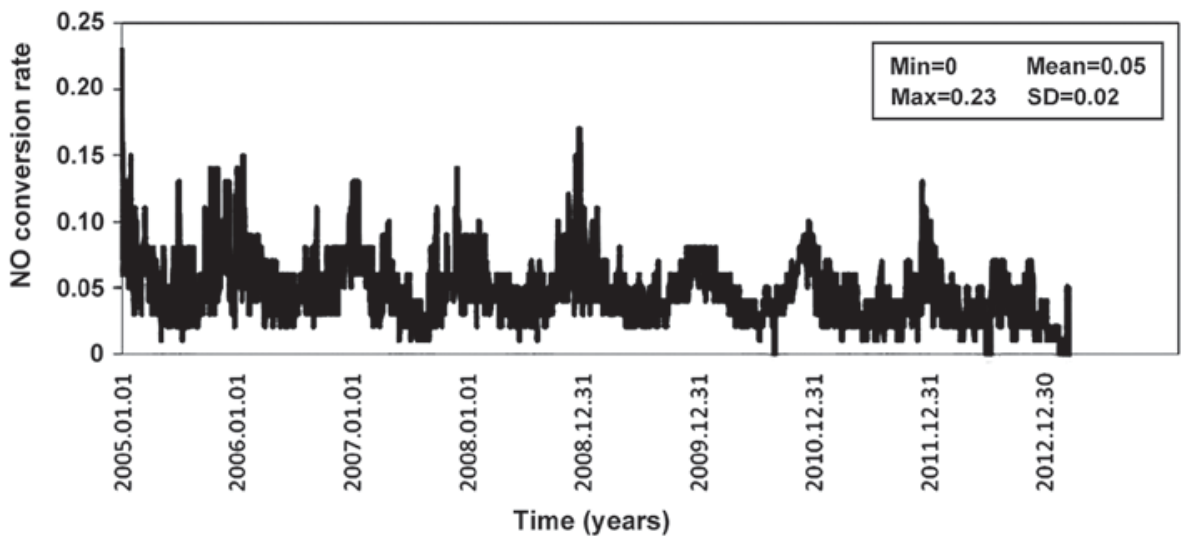

Figure 3. The variation of NO conversion rate during 2004-2012.

Autoregressive Moving Average (ARMA), Auto Regression Integrated Moving Average (ARIMA) and Moving Average, statistical models were used for the factor fluctuation modeling over time. $\mathrm{P}<0.05$ indicates a statistically significant difference.

\section{Results}

Tables I-III show statistical analyses for cancer, air pollution, and meteorological parameters. As shown in Table I, the cancers studied in this survey did not match with any models. However, consistencies of air pollution and meteorological parameters are reported in Tables II and III.

Figs. 1-6 show variations in time of air pollutants more significantly for some studied substancies. As shown in figures, concentrations of $\mathrm{CO}, \mathrm{NO}, \mathrm{NO}_{2}$ and $\mathrm{NO}_{\mathrm{X}}$ decreased during the present study, while $\mathrm{O}_{3}$ concentration increased. There was a periodic alteration of the $\mathrm{CO}, \mathrm{NO}$ and $\mathrm{NO}_{\mathrm{X}}$ concentrations. Peak of pollutant concentrations was in the tenth month 


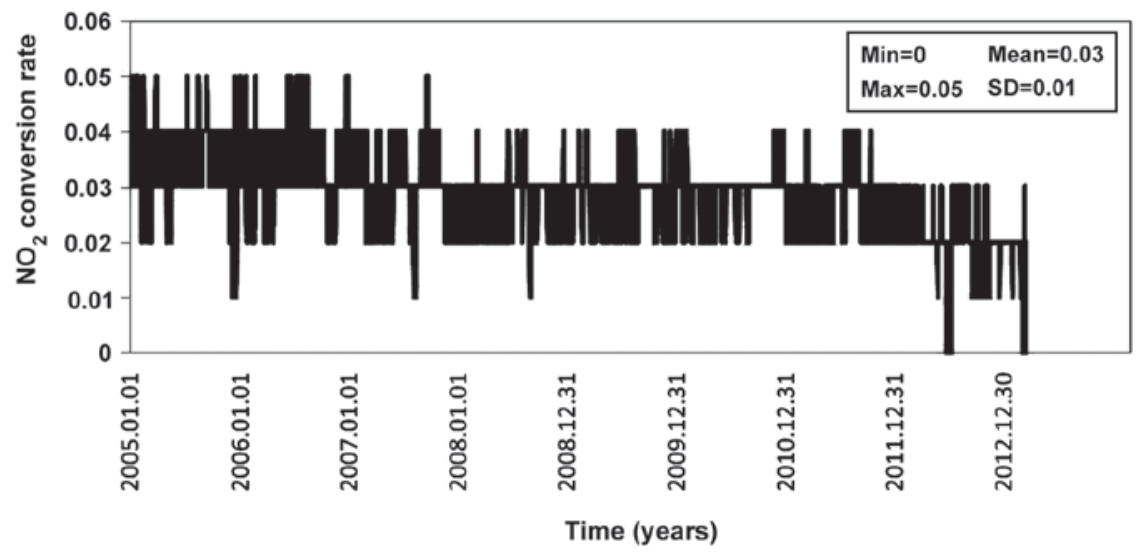

Figure 4. The variation of $\mathrm{NO}_{2}$ conversion rate during 2004-2012. $\mathrm{NO}_{2}$, nitrogen dioxide.

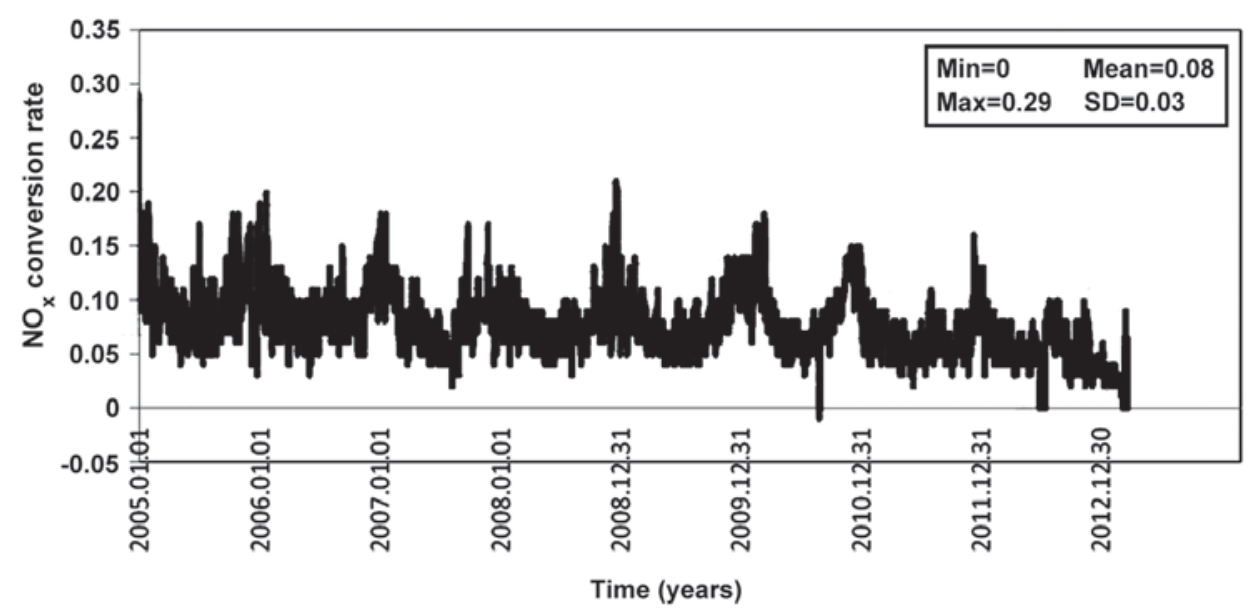

Figure 5. The variation of $\mathrm{NO}_{\mathrm{X}}$ conversion rate during 2004-2012.

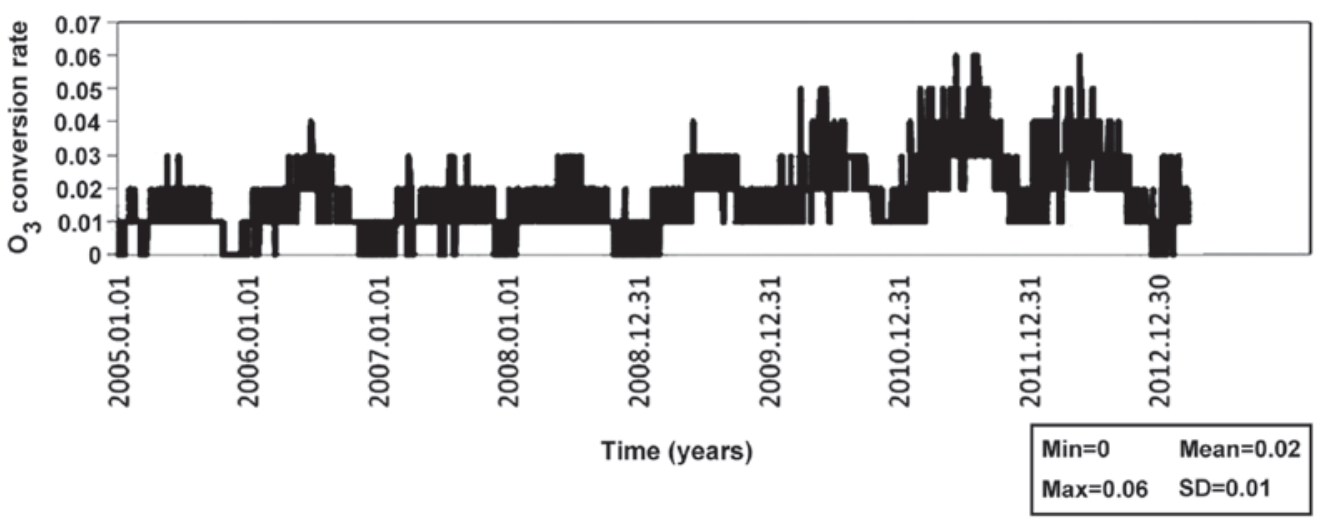

Figure 6. The variation of $\mathrm{O}_{3}$ conversion rate during 2004-2012. $\mathrm{O}_{3}$, ozone.

of each year. An extreme reduction occurred in subsequent six months. The trend of $\mathrm{O}_{3}$ concentration was quite reverse compared to the other pollutants, with peak of concentrations in the warmer months. Indeed, no specific pattern was observed for $\mathrm{NO}_{2}$ concentrations.

Figs. 7-9 show variation in time of weather conditions. Annually, highest rainfall level, the lowest temperature and the lowest wind speed occurred in the tenth month of each year. The lowest rainfall and the maximum temperature were observed approximately six months later.

Figs. 10-15 show the number of different cancer cases in the studied period. The above figures indicate that none of diseases follows a specific pattern. Also, average temperatures and precipitations level have no relationship with concentrations of CO. Instead, we observed the following relationships: i) both maximum wind speed and 


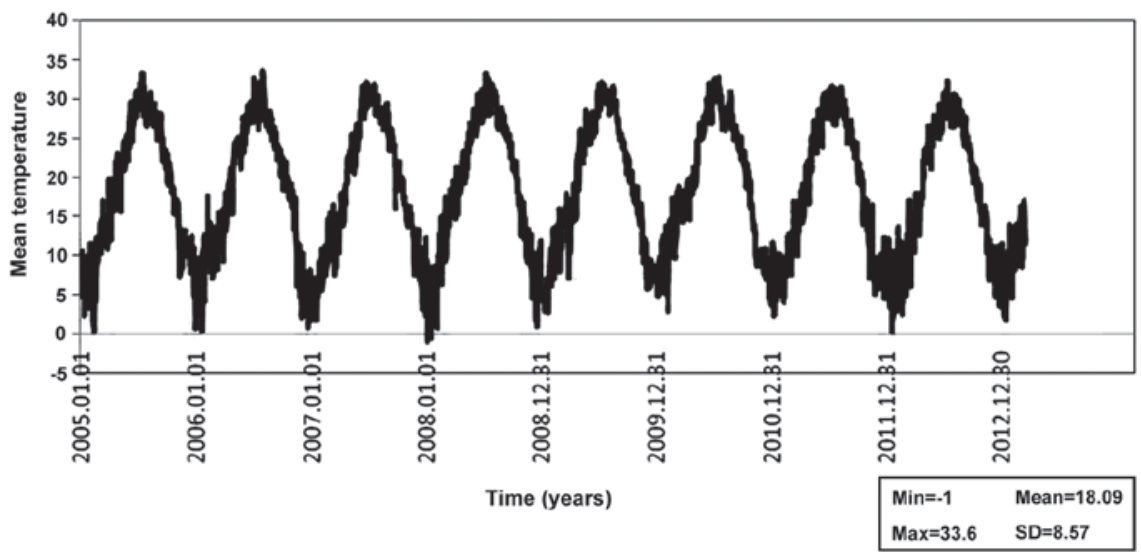

Figure 7. The variation of mean temperature during 2004-2012.

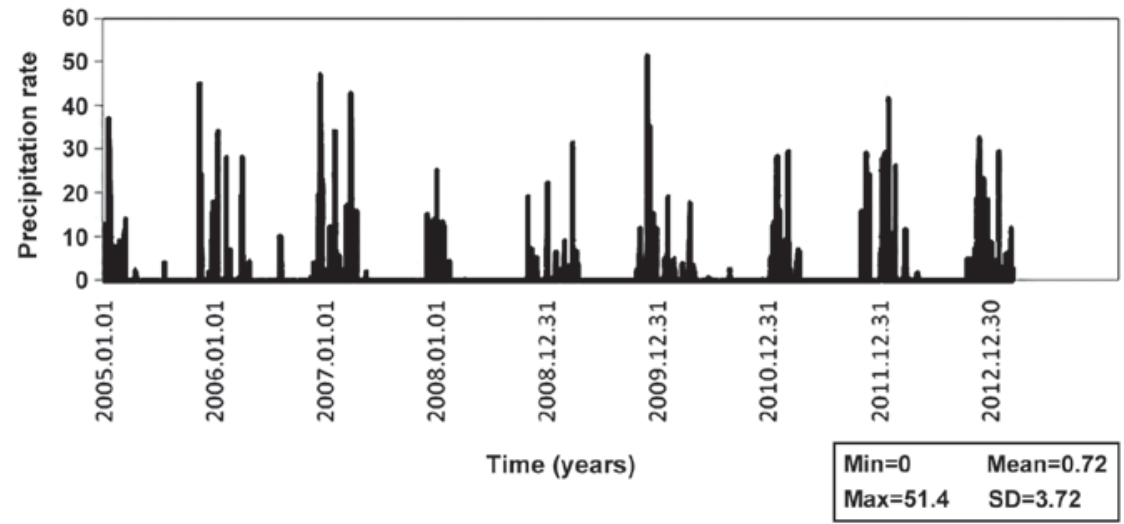

Figure 8. The variation of precipitation rate during 2004-2012.

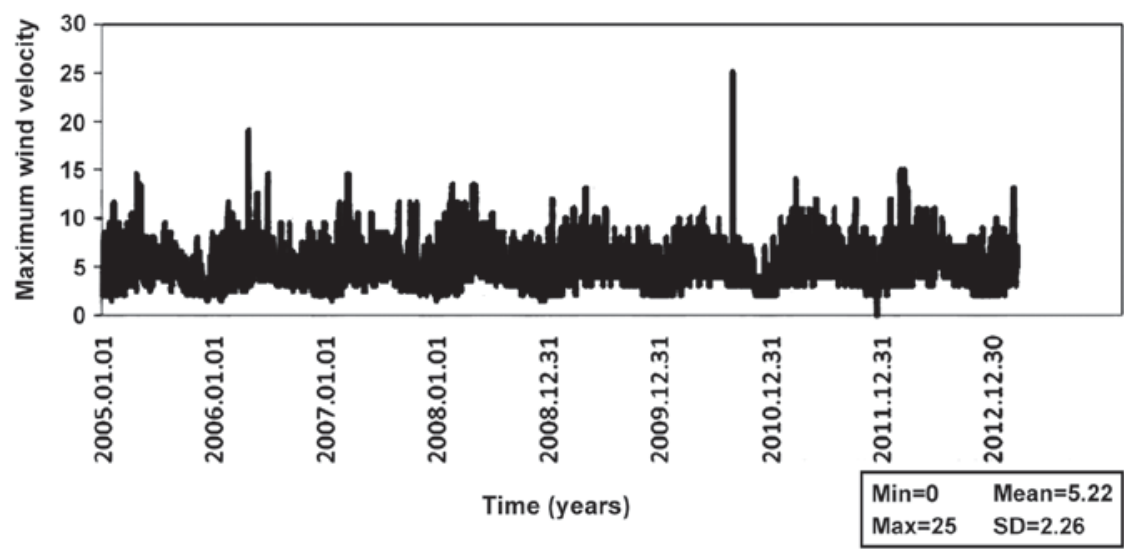

Figure 9. The variation of maximum wind velocity during 2004-2012.

$\mathrm{NO}_{2}$ concentration have a weak but significant inverse linear relationship with lung cancer in men $(\mathrm{P}<0.001$ and $\mathrm{r}<-0.079)$; ii) in the total population, lung cancer has a weak but significant inverse linear relationship with the maximum wind speed and $\mathrm{NO}_{2}$ concentration $(\mathrm{P}<0.001$ and $\mathrm{r}<-0.085)$; iii) lymphatic cancer in women has a weak but significant inverse linear relationship with concentration of $\mathrm{NO}_{2}(\mathrm{P}<0.001$ and $\mathrm{r}<-0.052)$; iv) myeloid cancer in men has a weak but significant inverse linear relationship with
$\mathrm{NO}_{2}$ concentration $(\mathrm{P}<0.001$ and $\mathrm{r}<-0.043)$; v) lymphoid cancer in men and women has a weak but significant inverse linear relationship with concentration of $\mathrm{NO}_{2}(\mathrm{P}<0.001$ and $\mathrm{r}<-0.042$ ); and vi) total cancers have a weak but significant inverse linear relationship with the maximum wind speed and $\mathrm{NO}_{2}$ concentration $(\mathrm{P}<0.001$ and $\mathrm{r}<-0.092)$.

Generally, it seems that concentration of $\mathrm{NO}_{2}$ in Shiraz has a weak and inverse relationship with the mortality rate of lung and lymph node cancers. Furthermore, in some cases the 


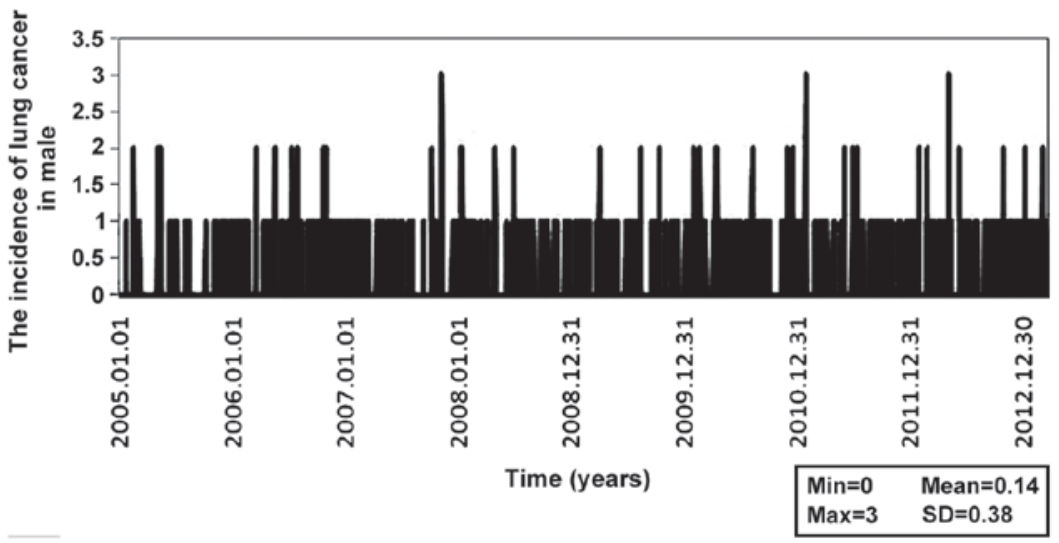

Figure 10. The incidence of lung cancer in men in 2004-2012.

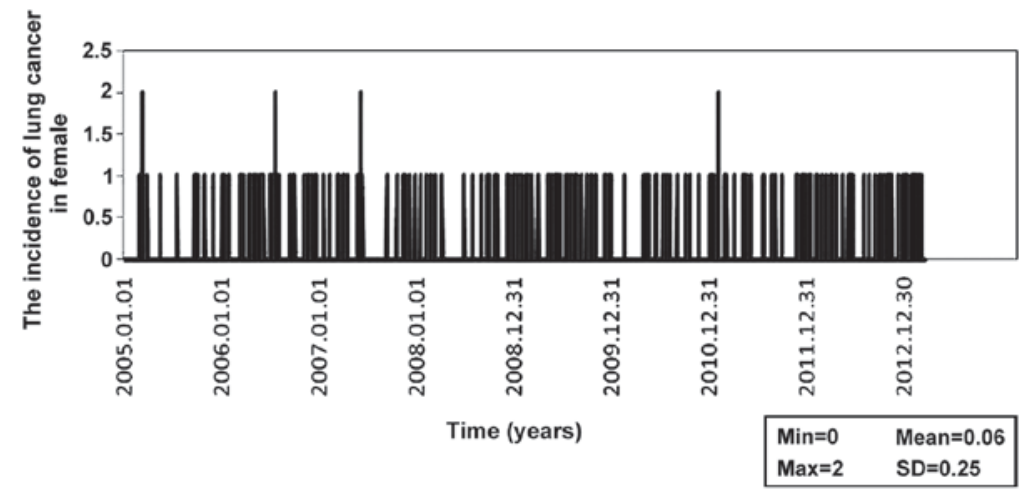

Figure 11. The incidence of lung cancer in women in 2004-2012.

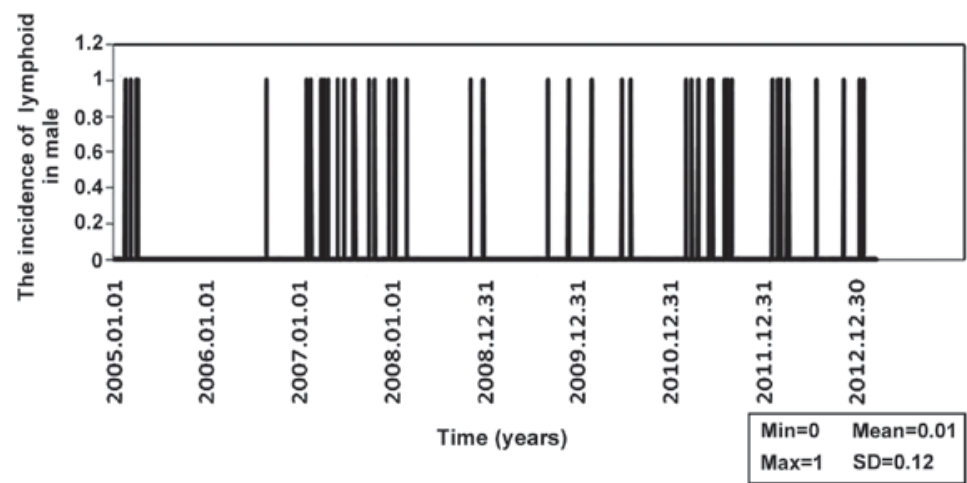

Figure 12. The incidence of lymphoid in men in 2004-2012.

maximum wind speed has the same relationship with mortality of lung and lymph node cancers.

According to our statistical analysis, it seems there is a weak relationship between the pollutant levels and the above mortality.

\section{Discussion}

The results of the present study indicated that the number of deaths due to lung cancer and leukemia had a weak but significant relationship $(\mathrm{P}<0.05)$ with the concentration of $\mathrm{NO}_{2}$ and $\mathrm{CO}$ in the air.
Wong et al studied (5) epidemiological and experimental issues relating to genotoxic effects of air pollution and DNA reporting that due to the increasing number cases of lung cancer, it would be essential that governments pay special attention to all preventive measures to reduce air pollution, to develop clean energy programs, and to improve research on investigation of carcinogenesis effects of air pollution.

Study of Chalbot et al on $\mathrm{PM}_{2.5}$ in USA in 2014 showed that implementation of law and air pollution regulations had major effects even in areas with high main risk factors of mortality as obesity and smoking (21). 


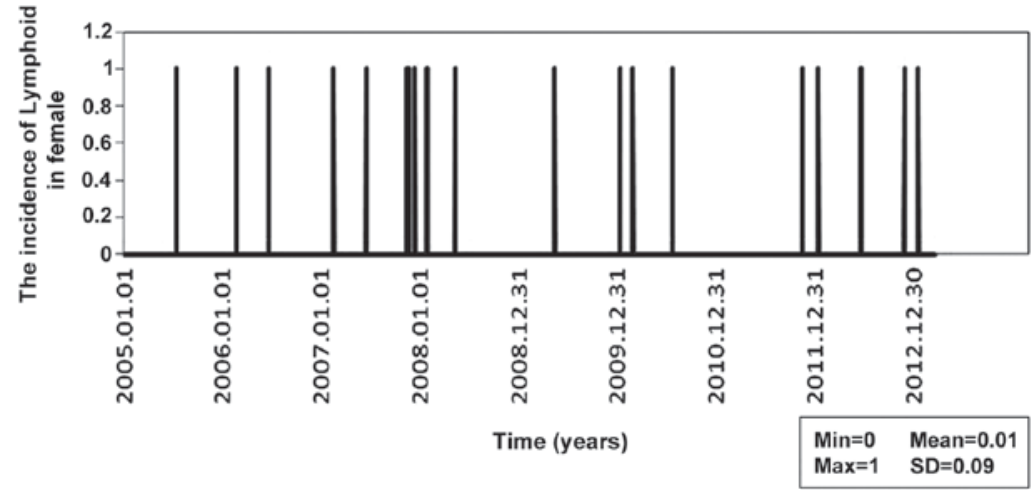

Figure 13. The incidence of lymphoid in women in 2004-2012.

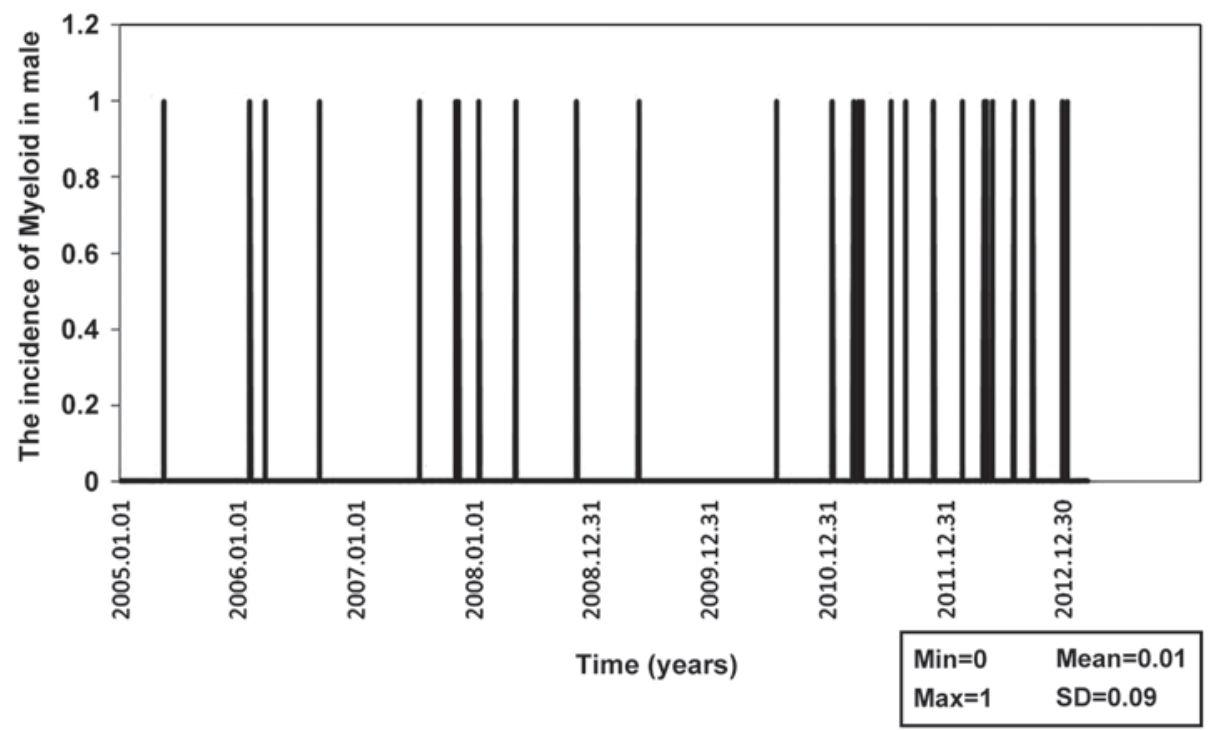

Figure 14. The incidence of myeloid in men in 2004-2012.

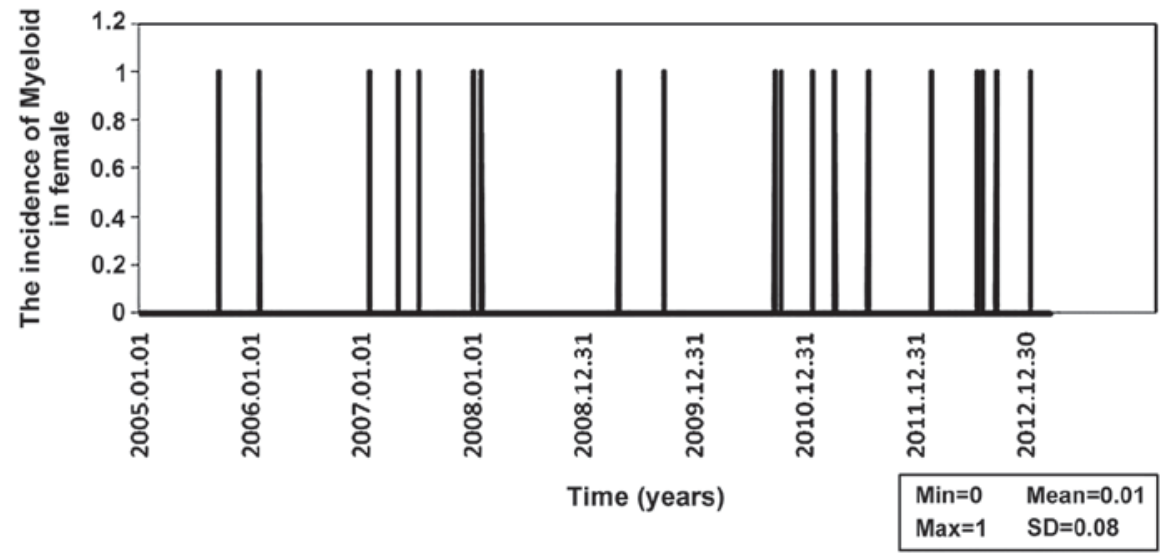

Figure 15. The incidence of myeloid in women in 2004-2012.

Pope et al revealed prolonged contact with fine particles by combustion was related to lung cancer and cardiovascular disease (13). Vineis and Husgafvel-Pursiainen demonstrated that air pollution increased lung cancer, especially in combination with some other known risk factors such as smoking, passive cigarette smoke, and occupational exposures. The present study also showed that organic air pollutants, especially PAH compounds, had genotoxic and oxidative effects on DNA (12).

Gilliland et al proclaimed that short-term changes in the amount of $\mathrm{O}_{3}$ caused respiratory diseases that led to absence of 10-12-year-old children from school. Therefore, adverse effect 
of $\mathrm{O}_{3}$ on children's health has been established (11). Previous studies carried out in Tehran city also showed that $\mathrm{CO}, \mathrm{SO}_{2}$ and $\mathrm{NO}_{2}$ were the most important causes of deaths due to heart disease (7). Masjedi et al showed the concentrations of $\mathrm{SO}_{2}$ and $\mathrm{NO}_{2}$ had a significant correlation with asthma attacks in Tehran (22).

Previous studies in Ahwaz city carried out by Zolghi et al, using appropriate models, indicated that the percentage of deaths due to air suspending $\mathrm{PM}_{10}$ measured in 2010 was $17.5 \%$ which was $5.5 \%$ higher than the preceding year (23). Research in Australia, revealed that the most important reasons for hospital emergency admissions for respiratory disease were $\mathrm{PM}_{10}$ such as ozone concentrations (24).

The study of Lewis et al also showed the major reasons of hospital admission of children were asthma attacks due to high concentrations of $\mathrm{PM}_{2.5}$ and ozone (25).

Moreover, Italian studies reported significant correlation between air pollution in urban area and risk of childhood leukemia $(26,27)$.

However, the present study is unique as it shows the correlation among factors such as air pollutants, local meteorological conditions, and mortality rate due to cancer in Shiraz and help local authorities, politicians and all those involved in this topic to pay special attention to these issues and to control sources of air pollution such as industries and transport systems and to standardize use of fuels. Therefore, special attention should be paid to sources of these pollutants and we need better management to decrease air pollutant concentrations through, e.g., using clean energy in respect to fossil fuels, better managing of urban traffic planning, improved public transport service and car sharing.

\section{Acknowledgements}

The authors would like to thank the Deputy of Research and Technology of Shiraz University of Medical Sciences for their financial support of this project no. 9301218095.

\section{References}

1. Wong MC, Tam WW, Wang HH, Lao XQ, Zhang DD, Chan SW, Kwan MW, Fan CK, Cheung CS, Tong EL, et al: Exposure to air pollutants and mortality in hypertensive patients according to demography: A 10 year case-crossover study. Environ Pollut 192: 179-185, 2014.

2. EPA: Criteria Air Pollutants. NAAQS Table. https://www.epa gov/criteria-air-pollutants/naaqs-table. Accessed January 9, 2017.

3. Oliveri Conti G, Heibati B, Kloog I, Fiore M and Ferrante M: A review of AirQ models and their applications for forecasting the air pollution health outcomes. Environ Sci Pollut Res Int: 2017. https://doi.org/10.1007/s11356-016-8180-1.

4. Cohen AJ: Outdoor air pollution and lung cancer. Environ Health Perspect 108 (Suppl 4): 743-750, 2000.

5. Wong IC, Ng YK and Lui VW: Cancers of the lung, head and neck on the rise: Perspectives on the genotoxicity of air pollution. Chin J Cancer 33: 476-480, 2014.

6. Calderón-Garcidueñas L, Azzarelli B, Acuna H, Garcia R, Gambling TM, Osnaya N, Monroy S, DEL Tizapantzi MR, Carson JL, Villarreal-Calderon A and Rewcastle B: Air pollution and brain damage. Toxicol Pathol 30: 373-389, 2002.

7. Henriksson J and Tjälve H: Manganese taken up into the CNS via the olfactory pathway in rats affects astrocytes. Toxicol Sci 55: 392-398, 2000.

8. Morgan KT and Monticello TM: Airflow, gas deposition, and lesion distribution in the nasal passages. Environ Health Perspect 85: 209-218, 1990
9. Nakashima $T$, Tanaka $M$, Inamitsu $M$ and Uemura $T$ : Immunohistopathology of variations of human olfactory mucosa. Eur Arch Otorhinolaryngol 248: 370-375, 1991.

10. Paik SI, Lehman MN, Seiden AM, Duncan HJ and Smith DV: Human olfactory biopsy. The influence of age and receptor distribution. Arch Otolaryngol Head Neck Surg 118: 731-738, 1992.

11. Gilliland FD, Berhane K, Rappaport EB, Thomas DC, Avol E, Gauderman WJ, London SJ, Margolis HG, McConnell R, Islam KT and Peters JM: The effects of ambient air pollution on school absenteeism due to respiratory illnesses. Epidemiology 12: 43-54, 2001.

12. Vineis P and Husgafvel-Pursiainen K: Air pollution and cancer: Biomarker studies in human populations. Carcinogenesis 26: 1846-1855, 2005

13. Pope CA III, Burnett RT, Thun MJ, Calle EE, Krewski D, Ito K and Thurston GD: Lung cancer, cardiopulmonary mortality, and long-term exposure to fine particulate air pollution. JAMA 287: 1132-1141, 2002.

14. Pope CA III, Thun MJ, Namboodiri MM, Dockery DW, Evans JS, Speizer FE and Heath CW Jr: Particulate air pollution as a predictor of mortality in a prospective study of US adults. Am J Respir Crit Care Med 151: 669-74, 1995.

15. Kloog I, Coull BA, Zanobetti A, Koutrakis P and Schwartz JD: Acute and chronic effects of particles on hospital admissions in New-England. PLoS One 7: e34664, 2012.

16. Zanobetti A, Redline S, Schwartz J, Rosen D, Patel S, O'Connor GT, Lebowitz M, Coull BA and Gold DR: Associations of $\mathrm{PM}_{10}$ with sleep and sleep-disordered breathing in adults from seven U.S. urban areas. Am J Respir Crit Care Med 182: 819-825, 2010.

17. Rice MB, Rifas-Shiman SL, Litonjua AA, Oken E, Gillman MW, Kloog I, Luttmann-Gibson H, Zanobetti A, Coull BA, Schwartz J, Koutrakis P, Mittleman MA and Gold DR: Lifetime exposure to ambient pollution and lung function in children. Am J Respir Crit Care Med 193: 881-888, 2016.

18. Calderón-Garcidueñas L, Mora-Tiscareño A, Ontiveros E, Gómez-Garza G, Barragán-Mejía G, Broadway J, Chapman S, Valencia-Salazar G, Jewells V, Maronpot RR, et al: Air pollution, cognitive deficits and brain abnormalities: A pilot study with children and dogs. Brain Cogn 68: 117-127, 2008

19. Miri M, Derakhshan Z, Allahabadi A, Ahmadi E, Oliveri Conti G, Ferrante $M$ and Aval HE: Mortality and morbidity due to exposure to outdoor air pollution in Mashhad metropolis, Iran. The AirQ model approach. Environ Res 151: 451-457, 2016.

20. Calderón-Garcidueñas L, Engle R, Mora-Tiscareño A, Styner M, Gómez-Garza G, Zhu H, Jewells V, Torres-Jardón R, Romero L, Monroy-Acosta ME, et al: Exposure to severe urban air pollution influences cognitive outcomes, brain volume and systemic inflammation in clinically healthy children. Brain Cogn 77: 345-355, 2011.

21. Chalbot MC, Jones TA and Kavouras IG: Trends of non-accidental, cardiovascular, stroke and lung cancer mortality in Arkansas are associated with ambient $\mathrm{PM}_{2.5}$ reductions. Int $\mathrm{J}$ Environ Res Public Health 11: 7442-7455, 2014.

22. Masjedi MR, Jamaati HR, Dokouhaki P, Ahmadzadeh Z, Taheri SA, Bigdeli M, Izadi S, Rostamian A, Aagin K and Ghavam SM: The effects of air pollution on acute respiratory conditions. Respirology 8: 213-230, 2003.

23. Zolghi E, Godarzi Gh, Gravandi S, Mohamadi M, Vosoghi Nayeri M, Visi E, et al: Estimate of cardiovascular and respiratory diseases related to particle matter pollutant in Tabriz air, northwest of Iran, 2011. J Ilam Univ Med Sci 22: 84-91, 2014.

24. Petroeschevsky A, Simpson RW, Thalib L and Rutherford S: Associations between outdoor air pollution and hospital admissions in Brisbane, Australia. Arch Environ Health 56: 37-52, 2001.

25. Lewis TC, Robins TG, Mentz GB, Zhang X, Mukherjee B, Lin X, Keeler GJ, Dvonch JT, Yip FY, O'Neill MS, et al: Air pollution and respiratory symptoms among children with asthma: Vulnerability by corticosteroid use and residence area. Sci Total Environ 448: 48-55, 2013.

26. Malagoli C, Malavolti M, Costanzini S, Fabbri S, Tezzi S, Palazzi G, Arcolin E and Vinceti M: Increased incidence of childhood leukemia in urban areas: A population-based case-control study. Epidemiol Prev 39: 102-107, 2015.

27. Filippini T, Heck JE, Malagoli C, Del Giovane C and Vinceti M: A review and meta-analysis of outdoor air pollution and risk of childhood leukemia. J Environ Sci Health C Environ Carcinog Ecotoxicol Rev 33: 36-66, 2015. 